\title{
EFFECT OF SEEDING RATE ON YIELD DISTRIBUTION OF TAMA/RAHU GREENFEED AT TWO SITES IN SOUTHLAND
}

\author{
R. J. M. HAY and D. L. RYAN \\ Grasslands Division, DSIR, Private Bag, Gore
}

\section{Abstract}

Rahu ryecorn, the most productive cereal under grazing in this environment, was evaluated at four seeding rates in combination with Tama ryegrass also at four seeding rates and compared with pasture. The trial was direct-drilled at two sites, Gore and Riversdale, in early autumn 1975. At Gore the optimum sowing rate combination . we $7 \Omega_{0} \mathrm{k} / \mathrm{h}$. Rahu with $30 \mathrm{hg} / \mathrm{ha}$ Tama. This yielded $8710 \mathrm{~kg} \mathrm{DM} / \mathrm{ha}$ from 5 grazings to the end of October. The drier Riversdale site yielded $6260 \mathrm{~kg} \mathrm{DM} / \mathrm{ha}$ over the same period at an optimum sowing rate combination of $140 \mathrm{~kg} / \mathrm{ha}$ Rahu with $30 \mathrm{~kg} / \mathrm{ha}$ Tama. Tiller number, tiller weight and quality measurements are presented and discussed, together with yield data in relation to all grass Farming management in Southland.

\section{INTRODUCTION}

SouthLAND's winter pasture shortage, graphically illustrated by Brown and Harris (1972), is supplemented by feeding out herbage conserved as hay or silage during late spring and summer when feed supplies are surplus to animal requirements. There is, however, a critical period before and immediately after lambing when stock demand herbage of higher quality than is provided by conserved feed (Harris and Hickey, 1977). The amount of pasture available to meet this requirement necessarily limits the number of ewes that can be carried on an all-grass farm system.

A method of overcoming this problem is to use greenfeeds to supplement autumn-saved pasture and pastures rotationally grazed during winter and early spring.

Cutting trials at Gore by Harris and Johnston (1969) and Harris et al. (1973) showed 'CRD' ryecorn (Secale cereale) to be the highest yielding cereal, outproducing 'Grasslands Tama' Westerwolds ryegrass (Lolium multiflorum) in early winter. In late winter and early spring, however, Tama ryegrass outyielded ryecorn.

Verification of these results under grazing was obtained in 1974, at three climatically diverse sites in Southland, at Gore, 
Riversdale, and Wendon (Hay and Ryan, unpubl.), where several cereals were evaluated both alone and in combination with Tama to take advantage of variety/seasonal growth differences. At all sites the combination of Rahu (a selection from CRD ryecorn) with Tama was the highest yielding, and this combination gave $30 \%$ greater dry matter (DM) production than Tama alone, confirming work by Vartha and Rae (1973) in Canterbury. Bircham and Crouchley (1974) demonstrated in the Wairarapa that the distribution of yield can be markedly influenced by seeding rates of the mixtures, so trials were initiated in 1975 to investigate this effect at the two most climatically diverse sites, Gore and Riversdale.

\section{EXPERIMENTAL METHODS}

The Riversdale site was on a shallow stony silt loam associated with yellow-grey earth soils, and is temporarily classified as a Riversdale silt loam (J. C. Bruce, pers. comm.) . This site is representative of some 40000 ha of Southland classed by Long (1966) as dry land and it receives on average $625 \mathrm{~mm}$ annual rainfall. Droughts often occur owing to the variability of summer rainfall together with high evaporation resulting from the prevailing northeast and northwest winds (Garnier, 1958). Winters are drier and colder than at Gore. The Gore site, which receives an average rainfall of $825 \mathrm{~mm}$, was on a Waimumu silt loam, a B-gleyed yellow-grey earth (J. G. Bruce, pers. comm.) .

Seeding rates were for Tama $0,10,20,30$, and for Rahu 0 , $35,75,140 \mathrm{~kg} / \mathrm{ha}$, sown on 26.2 .75 and 3.3.7.5 at Gore and Riversdale, respectively. Combinations of all sowing rates were obtained by cross-drilling each species - two $2.5 \mathrm{~m}$ drill widths for the Tama at right-angles to three drill widths of Rahu. The $0 \times 0$ treatment was a pasture control. There were four replicates.

At both sites the seed was direct-drilled into paraquated pasture (apart from unsprayed pasture controls) with a triple disc drill. After drilling, the area was topdressed with $250 \mathrm{~kg} / \mathrm{ha}$ $25 \%$ potassic superphosphate $(\mathrm{O}-7-12))$ together with $125 \mathrm{~kg} / \mathrm{ha}$ of urea (46-O-O). Both sites received at least $25 \mathrm{~mm}$ of rain in the week following sowing, resulting in good establishment. Fertilizer was applied after each grazing to compensate for gross nutrient depletion associated with day grazing by sheep. Nutrient return was based on $33 \%$ of the mean plot DM yield (R. A. Carran, pers. comm.) at $4.5 \% \mathrm{~N}, 0.35 \% \mathrm{P}, 0.3 \% \mathrm{~S}, 2.5 \% \mathrm{~K}$, 
$0.2 \% \mathrm{Mg}$. Fensulfathion insecticide was surface applied at $2 \mathrm{~kg}$ a.i./ha after drilling to control grassgrub (Casfelytra zealandica) and porina (Wiseana spp.).

Five grazings, commencing on 9.4 .75 at Gore and 24.4.75 at Riversdale, were completed by the end of October. Dry matter production measurements were taken immediately before grazing by cutting four $0.25 \mathrm{~m}^{2}$ quadrats per plot with hand shears to $2 \mathrm{~cm}$ when the average plot height reached $15 \mathrm{~cm}$. Stocking rate was adjusted to achieve defoliation to the required height in about 48 hours, and if necessary trial areas were topped after grazing.

Tiller numbers and tiller weights were determined for both Tama and Rahu from cutting five $0.05 \mathrm{~m}^{2}$ quadrats per plot to ground level in autumn and late winter. Samples were bulked from the four replicates for in vitro organic matter digestibility and nutrient analyses.

\section{RESULTS}

\section{Dry Matter Production}

Total DM production data for the two sites are presented in Table 1.

Production from Riversdale averaged $65 \%$ of that from Gore.. DM increased linearly up to the highest seed rate combination at Riversdale, but at Gore the response to seeding rate had levelled off at a lower Tama/Rahu mixture of $30 / 70 \mathrm{~kg} / \mathrm{ha}$. At both sites the DM production from the monocultures increased with seeding rate, with Tama being markedly superior to Rahu

TABLE 1: TOTAL PRODUCTION (kg DM/ha) FOR TWO SITES IN SOUTHLAND

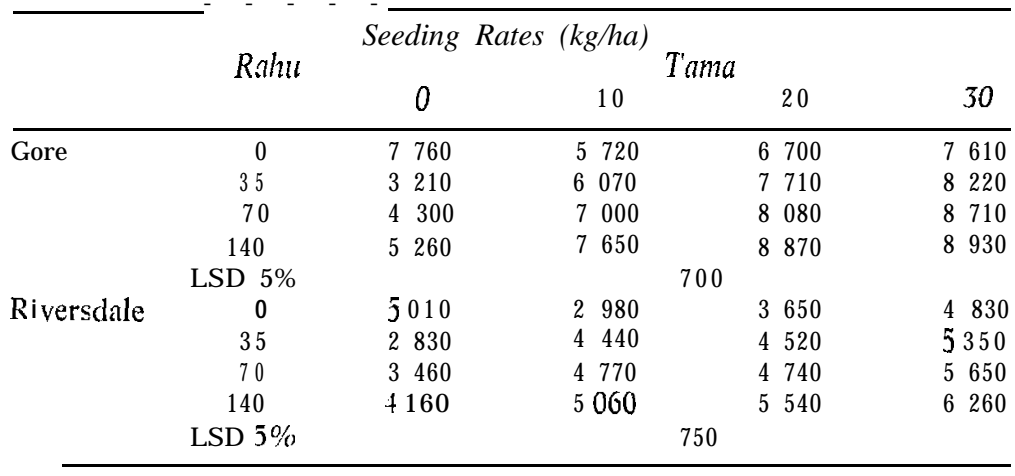


at the Gore site. Total production from pasture was only surpassed at the higher seeding rate combinations in both trials. Total production from the highest seeding rate combination was $15 \%$ and $25 \%$ higher than that of pasture at Gore and Riversdale, respectively. At neither site did any monoculture treatment produce as much as the pasture controls.

The distribution of this DM production for Gore from sowing until 1.11 .75 is presented in Fig. 1.
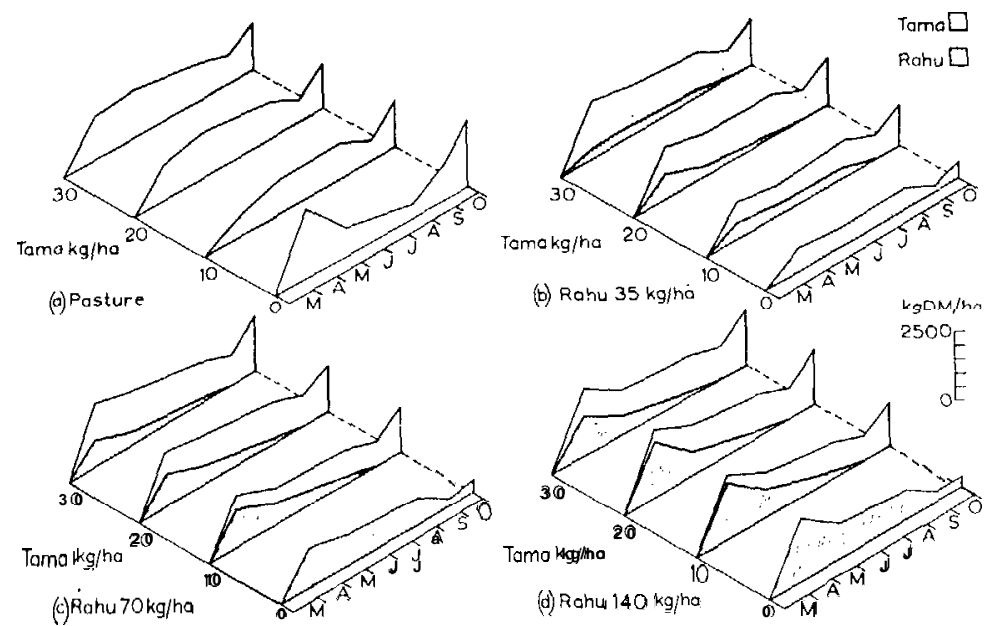

FIG. 1: Distribution of dry matter production for Gore.
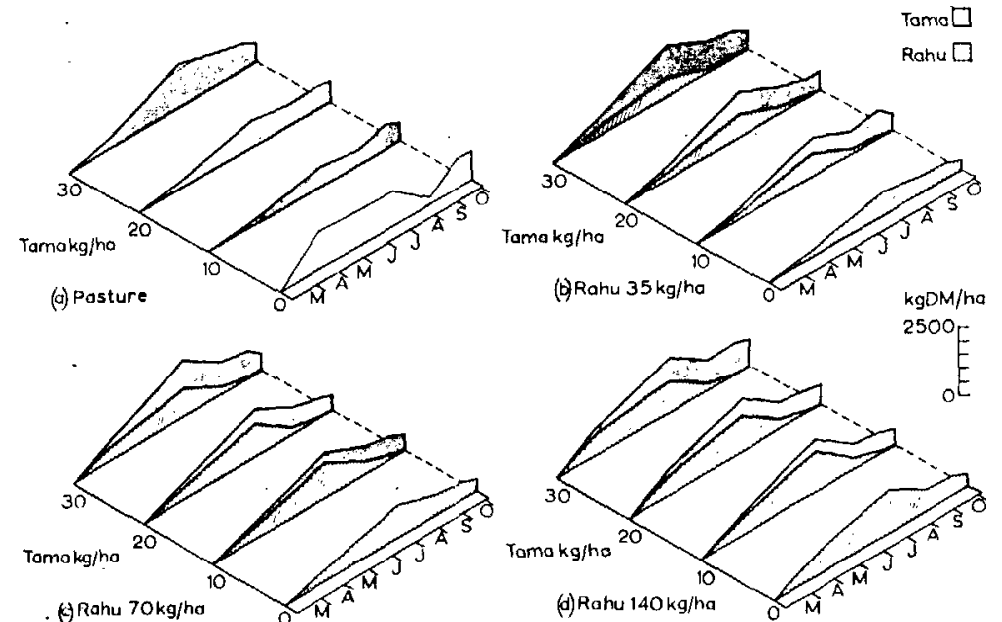

$\Leftrightarrow$ Rahu $70 \mathrm{~kg} / \mathrm{ho}$

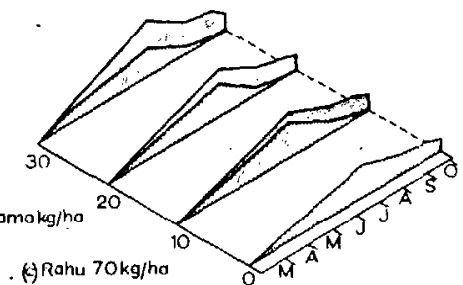

Fig. 2: Distribution of dry matter production for Riversdale. 
The pasture plots produced most of their yield in autumn and late spring and their growth for the June-August period was only one-third of that of many of the Tama/Rahu mixtures. Production from Rahu monocultures declined after the third grazing; however, the Rahu component of the mixtures produced 75 to $90 \%$ of its contribution from the first two grazings. Almost nu Rahu remained in the mixtures at the mid- and late spring grazings. The drop in production at the fourth sampling on all treatments except the pasture controls was due to the trial being grazed when soil conditions were very wet, which shows the sensitivity of winter annuals to this treatment compared with pasture (Harris et al., 1973).

The distribution of DM production for Riversdale (Fig. 2) shows similar trends to those at Gore.

Important site differences were the extremely low growth of pastuite at Riversdale aringofugust and early September, which amounted to only one-fifth of that from the treatments sown with $30 \mathrm{~kg} / \mathrm{ha}$ Tama; and the slow initial growth of both species, particularly Rahu which did not produce its maximum yield until the second grazing and tended to dominate the mixtures for a longer period than at Gore.

\section{Tilier Population}

The main effects of plot tiller numbers presented in Table 2 show that at one month from sowing the Riversdale site had approximately half the tiller numbers at all seeding rates for both species compared with Gore. At both sites there was a marked response to seeding rate within each species, with tiller numbers more than doubling from lowest to highest seeding rate. At this sampling there was very little depression of tiller numbers of one species with increasing seeding rate of the other. This was particularly so at Riversdale.

By late winter, tiller numbers at Riversdale had increased to be similar to those at Gore. Seeding rate of Tama was by then exercising a significant depression on Rahu tiller numbers with an acceptable population being achieved only in the absence of Tama. The low population of Rahu by late winter had little effect on Tama tiller numbers, particularly at Gore.

The effect of seeding rate on dry weight/tiller from monocultures is presented in Table 3. Weights were determined only for the Gore site on 5.8.75. Significantly higher values were recorded at the lowest seeding rate of $10 \mathrm{~kg} / \mathrm{ha}$ Tama than at the higher two rates. This did not occur with Rahu. 
TABLE 2: MEAN TILLFR. NUMBERS- PER $\mathrm{m}^{2}$ - OF; COMPONENTS OF GREENFEED MIXTURES SOWN AT DIFFERENT SEEDING RATE COMBINATIONS (MAIN EFFECTS)

\begin{tabular}{|c|c|c|c|c|c|}
\hline & & Tama & Ruhu & Tama & Rahu \\
\hline \multicolumn{6}{|l|}{ Gore } \\
\hline \multirow{5}{*}{ Tama (kg/ha) } & 0 & & & & \\
\hline & 10 & $\overline{640}$ & 1300 & 1840 & $\begin{array}{r}1650 \\
625\end{array}$ \\
\hline & 20 & 1175 & 1025 & 2415 & 370 \\
\hline & 30 & I 550 & 1120 & 2575 & 330 \\
\hline & LSD $5 \%$ & 100 & 140 & 225 & 135 \\
\hline \multirow[t]{5}{*}{ Rahu (kg/ha) } & 0 & 1375 & & 2495 & - \\
\hline & 35 & 1200 & 665 & 2610 & 495 \\
\hline & 70 & 1010 & 1105 & 2255 & 750 \\
\hline & 140 & 935 & 1660 & 1760 & 990 \\
\hline & LSD $5 \%$ & 115 & 120 & 255 & 115 \\
\hline \multicolumn{6}{|l|}{ Riversdale } \\
\hline \multirow{2}{*}{\multicolumn{2}{|c|}{ T) }} & & & & \\
\hline & & Tama & Rahu & Tana & Rahu \\
\hline \multirow{5}{*}{ Tama (kg/ha) } & 0 & $=$ & 705 & $-\overline{1}$ & 1455 \\
\hline & 10 & 290 & 705 & 1120 & 850 \\
\hline & 20 & 545 & 705 & 1825 & 640 \\
\hline & 30 & 720 & 705 & 2065 & 495 \\
\hline & LSD $5 \%$ & 60 & 95 & 210 & 145 \\
\hline \multirow[t]{5}{*}{ Rahu (kg/ha) } & 0 & 530 & - & 2255 & - \\
\hline & 35 & 450 & 335 & 1760 & 735 \\
\hline & 70 & 510 & 640 & 1472 & 830 \\
\hline & 140 & 575 & 1135 & 1200 & 1010 \\
\hline & LSD $5 \%$ & 75 & 85 & 240 & 120 \\
\hline
\end{tabular}

TABLE 3: MEAN WEIGHT OF DM PER TILLER FOR TAMA AND RAHU AT THREE SEEDING RATES AT GORE MEASURED ON 5.8 .75

\begin{tabular}{lcccccc}
\hline & \multicolumn{3}{c}{ Tama } & \multicolumn{3}{c}{ Rahu } \\
\hline Seeding rate (kg/ha) & 10 & $\mathbf{2 0}$ & $\mathbf{3 0}$ & $\mathbf{3 5}$ & $\mathbf{7 0}$ & $\mathbf{1 4 0}$ \\
Wt/tiller (g) & 0.071 & 0.055 & $\mathbf{0 . 0 5 4}$ & $\mathbf{0 . 0 5 5}$ & 0.058 & $\mathbf{0 . 0 5 7}$ \\
LSD 5\% & & $\mathbf{0 . 0 0 6}$ & & & $\mathbf{0 . 0 1 3}$ & \\
\hline
\end{tabular}

TABLE 4: PERCENTAGE (IN VITRO) ORGANIC MATTER DIGESTIBILITY

\begin{tabular}{lcccc}
\hline Herbage & \multicolumn{2}{c}{ Gore } & \multicolumn{2}{c}{ Riversdale } \\
& $\begin{array}{c}\text { 2nd Grazing 3rd Grazing } \\
(\mathbf{2 7 . 5 . 7 5 )}\end{array}$ & $\begin{array}{c}\text { 2nd Grazing } \\
\text { (22. 8. 75) }\end{array}$ & C-14.7.75) & $\begin{array}{c}(11.9 .75) \\
\text { Tama }\end{array}$ \\
Rahu & $\mathbf{8 2 . 5}$ & $\mathbf{8 0 . 6}$ & $\mathbf{6 3 . 4}$ & $\mathbf{8 3 . 4}$ \\
Pasture & 81.2 & $\mathbf{8 3 . 0}$ & 81.8 & $\mathbf{8 0 . 4}$ \\
\hline
\end{tabular}




\section{Digestibility AND NUTRIENT LEVELS}

There was little difference in percentage digestibility between the three species at Gore (Table 4) for either of the two grazings. At Riversdale, however, digestibility of pasture was $18.5 \%$ lower than the mean of Tama and Rahu at the second grazing, and $6 \%$ lower at the third.

Nutrient levels as a percentage of DM for Gore at the third grazing are given in Table 5. $\mathrm{Mg}$ levels in all swards were low, particularly in the two winter annual varieties. Na levels in Rahu were half those of pasture and Tama.

TABLE 5: NUTRIENT LEVELS AS A PERCENTAGE OF DM FOR GORE AT 22.8.75

\begin{tabular}{|c|c|c|c|c|c|c|}
\hline Herbage & $\% \mathrm{~N}$ & $\% P$ & $\% K$ & $\% \mathrm{Ca}$ & $\% \mathrm{Mg}$ & $\% \mathrm{Na}$ \\
\hline Tama & 3.99 & 0.445 & 3.84 & 0.46 & 0.156 & 0.12 \\
\hline Rahu & 4.61 & 0.475 & 3.77 & $L 7.49$ & 0.167 & 0.06 \\
\hline Pasture & 4. 59 & 0.445 & 3.03 & 0.53 & 0.189 & 0.13 \\
\hline
\end{tabular}

\section{DISCUSSION}

Soil type and climate interacted to producc considerably lower dry matter production at Riversdale than at Gore. The high yields at both sites from the greenfeed crops were obtained from rotational grazing, a management system which exploits the winter growing potential of both species. As pointed out by Vartha and Rae (1973), in farming practice, the general tendency is to ration-graze greenfeeds with hay supplement and then set-stock before and after lambing rather than rotationally graze, A reduction in hay feeding, or preferably an increase in sheep numbers, could be achieved by rotationally grazing winter annuals, the quality of which is certainly no worse than, and is in early winter superior to pasture.

Most of the production over the critical pre-lambing and postlambing period (harvests 3 and 4) was provided by Tama. Importantly, this component of the mixtures was suppressed over this period only at its lowest sowing rate $(10 \mathrm{~kg} / \mathrm{ha}$ Tama $)$, so it seems that advantage can be taken of the early winter growth of Rahu without sacrificing early spring production from Tama. Consideration of total yield and its distribution indicates an optimum sowing rate combination at Gore of $30 \mathrm{~kg} / \mathrm{ha}$ Tama with $70 \mathrm{~kg} / \mathrm{ha}$ Rahu. On the drier Riversdale site which has a 
shallow soil, high seedling mortality can be overcome by using higher seed rates, and the combination of $30 \mathrm{~kg} / \mathrm{ha}$ Tama with $140 \mathrm{~kg} / \mathrm{ha}$ Rahu is justified.

Contrary to the results of Bircham and Crouchley (1974), in both environments in Southland the ryecorn component in the mixtures had disappeared by the fourth grazing after making a significant contribution to yield in the first two. The difference may well have been due to the variety of ryecorn used in this work. If this is so, the writers consider Rahu to have considerable advantages over the variety 'CRD' when used in mixtures, as it allows the Tama component of the sward to express its early spring growth potential.

Tiller number data in late winter indicated that there was very little suppression of Tama even though mixtures had been dominated by Rahu. It appears that enough Tama tillers survive, even with $140 \mathrm{~kg} / \mathrm{ha}$ Rahu, to ensure good spring growth, first through compensatory early spring tillering (in evidence at the second tiller count), and secondly through greater yield per tiller where the Tama population is lower (Table 3).

Although ryecorn recovers from grazing better than any other cereal (Vartha and Rae, 1973; Scott, 1976) its high growing point and its early flowering make it vulnerable to hard grazing especially in the late winter. These features combined to remove Rahu from the swards of both trials at this time, as demonstrated in Table 2.

The low digestibility value for pasture obtained at Riversdale at the second grazing can be attributed to the severe frosting experienced every year in this region during May-July (Garniet, 1958) and the physiological age of perennial pasture compared with the winter-active annual species, at the time of sampling (Sears and Goodall, 1941). In spring this difference had largely disappeared.

Tama and Rahu in early spring at Gore were barely adequate in magnesium (see Middleton, 1976) which demonstrates the low plant-available magnesium status of this soil, especially as magnesium was applied in the fertilizer return. The low level of sodium in Rahu compared with both Tama and pasture has been confirmed in other work (Hay and Ryan, unpubl.). In the practical situation this could be overcome to some extent with the use of agricultural salt licks.

The distribution of yield from the greenfeed mixtures changes the shape of the pasture production curve, giving three to five times more feed in mid-winter than pasture. This is of consider- 
able importance to intensive all-grass sheep farmers in Southland as it provides high quality feed at a critical time, and may lift the restraint on carrying capacity presently imposed by pasture availability in late pregnancy and at lambing.

\section{ACKNOWLEDGEMENTS}

Mrs N. Heaps, M. J. Hickey and J. D. Turner, Grasslands Division, DSIR, Gore, for technical assistance; Miss D. Jessop and P. Ncs, Grasslands Division, DSIR, Palmerston North, for in vitro digestibility and chemical analysis. My thanks for the co-operation from N. L. Shallard on whose property the Riversdale trial was situnted.

\section{REFERENCES}

Bircham, J. S.: Crouchley, G., 1974. Proc. N.Z. Agron. Soc., 4: 57-9.

Brown, K. R.: Harris, A. I."1972. Proc. N.Z. Grassld Ass., 34: 49-65.

Carnicr, B. J., 1958. The Climate of $\mathrm{New}$ Zealand. Edward Arnold, London.

Harris, A. J.; Hickey, M. J., 1977. Proc. 13th int. Grassld Congr., Leipzig: in press.

Harris, A. I.; Johnston, J. M., 1969. N.Z. /l Agric., 1 /9 (3): 45.

Harris, A. J.; Brown, K. R.; Turner, I. D.; Iohnston, J. M.; Ryall, D. L.; Hickey, M. J.. 1973. N.Z. Jl exp. Agric., I: 139-63.

Long, P. A.. 1966. N.Z. Soil Bur. Rep. No. 3.

Middleton, K R., 1976. N.Z. /l Agric., 153 (3): 71-2.

Scott. W. R.. 1976. Proc. 26th Lincoln Coll. Fonrs' Conf: 25-31

Sears: P. D.; Goodall. V. C., 1941. N.Z. /l Sci. Technol., 23A: 294-301.

Vartha, E. W.; Rae. S. J., 1973. Proc. N.Z. Grassld Ass., 34 (2): 196-76. 